\title{
THE NEGLECT OF THE AUTHOR IN NEW HISTORICISM
}

\author{
By Patricia Ana Marquez
}

When discussing the emergence of New Historicism in American scholarship, it is imperative to assess its origins and influences. Mikhail Bakhtin's exploration of the multiples of languages within the novel and Michel Foucault's analysis of the role of the author in texts both catapulted the development of New Historical scholarship. Today, this method of scholarship approaches the author as a non-autonomous agent subjected by the multiple social, political, and cultural forces of his or her era. Similarly, literature is perceived as an art form not unique from others and should be analyzed to point toward overarching power structures to the same degree as any other mode of representation. In considering the author as a social construct, many New Historicists neglect to perceive the author as a potential formulator or modifier of reigning ideology. The fact of the matter is that literature is able to shape the ideology of a society, not merely represent it. In viewing the author as a construct of his time period, critics fail to attempt to determine which literary works were revolutionary in their ability to manipulate and change a given society's underlying modes of thinking and practice.

This essay will explore the primary components of New Historicism that have resulted in this current analysis of the role of the author in literary theory. I will address the origins of each component through the scope of influential works on the role of the author in Bakhtin's presentation of "ideological products" within Discourse in the Novel (1935) and Michel Foucault's "What is an Author?" (1969), which disputed the reliability of an autonomous author. These two theorists provided the foundations for New Historical analysis of the author, which has become the dominant form of criticism in late-twentieth century American academia. The 
ultimate objective of this essay is to show how New Historicists appropriated these works and how their subsequent analyses and methods prove to be disadvantageous when applied to the role of the author. So often in literary scholarship today the author is relegated as a construct of society uncommitted to challenging the ideology of society, serving merely as an ideological slave to his or her dominant power structures. This essay will attempt to demonstrate that, contrary to the most common and popular methodological practices which New Historicism is based upon, the author is not a construct of their ideological formations but is a dynamic participant in ideological shifts that occur during a given historical period. Furthermore, our aim should be to isolate the literary works that are most influential, politically active, and indicative of dynamic ideological shifts, which can be achieved by studying author biography and intentions.

Stephen Greenblatt, largely considered the founder of New Historicism, first defined the school in his introduction to The Power of Forms in the English Renaissance (1982). He explains that prior historicism is monological, its goal being to detect a singular political vision held by the literate class or total population. New Historicism is a break from this method of historical interpretation as well as from earlier formalist criticism (5). Literature, Greenblatt claims, “mirrors” the era’s beliefs, but from a "safe distance.” In turn, he explains that although the distinction between artistic production and the politics of the time exists, it is no longer intrinsic to the texts because they are "constantly redrawn by artists, audiences, and readers" (6). The objective for New Historicists, therefore, is to detect the overarching network of institutional ideologies within literary texts and to discard authorial individualism and intentions.

Stephen Greenblatt’s most influential and preeminent work, Renaissance Self-Fashioning (1980), presented the loss of essential humanism in historical interpretation of sixteenth century 
English literature. In the introduction, Greenblatt addresses the idea of the "fashioning" of human identity during the English Renaissance, referring to the shaping of one's identity in sixteenth century England. Greenblatt stresses that there was less autonomy in self-fashioning during this time period with the emergence of the modern state. Because of the political, cultural, and religious institutions set in place, recognition of the ability to form one's identity came into view. Greenblatt believes that in regard to literature, scholarship encounters problems when it is limited to interpretation of an author's biography, since by doing so we cannot detect the "larger networks of meaning" in which the author and texts play a part (4).

Greenblatt further addresses the concept of self-identity in his epilogue. He curiously relays the story of a stranger who requests Greenblatt to play a part during an air flight to Boston. The man asks Greenblatt to mime the words, "I want to die," in order to prepare the man for the experience of hearing it from his dying son. Greenblatt finds he is incapable of doing this. For Greenblatt, pretending to express his wishes to die, when he certainly does not want to die, would be a "legal sentence" upon his own life and also a betrayal of his self-will. When exploring the autonomy of the human subject in fashioning one's identity, he found the fashioning by the subject's cultural institutions completely non-excludable. In fact, he decided the individual is "remarkably unfree," proving to be only a mere ideological product of his or her time. He concludes that identity is not chosen but is determinate as a "cultural artifact" (256). Greenblatt's work formulated a methodological practice of establishing that 1) there are ideological products to be found during the time period in which a text was written, and 2) that the notion of the self, when studying the author, is an ideological illusion since each author is incapable of mapping out his or her own identity. In turn, the author, and his or her work, is an artifact of his or her culture, another determinable figure representing and enslaved by the 
oppressive forces of his or her culture. This, as a result, is the death of humanism in literary scholarship, humanism defined as the generalized, essential human nature within all of us.

Greenblatt's attention to the prevailing social games in play during the English Renaissance is an arresting method of identifying the "intellectual, social, psychological, and aesthetic structures” that administer human identities (1). However, he neglects to view it as problematic in not identifying author intentions. For New Historicists, an author's intentions are re-interpreted by other writers or readers over time and therefore are not valuable. The establishment of this methodological practice sets the precedent for a severe disregard for what should be a vital reference point in literary theory. Uncovering an author's artistic invention and original intentions would shed insight into the influential mode of thinking that weighed heavily upon the author and, subsequently, readers of his or her work. Artistry is a reaction, a means of expressing disdain for a current system through hidden, yet fully decipherable subtext. The manner through which the author deliberately hides reactionary statements within language and format is influential on readers and therefore capable of eliciting mass social change. Even if a given literary work is reinterpreted over time, supposedly rendering author intentions inconsequential, critics should still establish the author's original intentions to decipher how and why these works were re-imagined. If literature is able to counter a reigning mode of ideology critics would benefit by not approaching the author as a "subject" but rather as a seditious individual refusing to be subjected by complex power structures through their own written expression. Thus, author intentions and biography is imperative to literary analysis.

Let us now interpret the New Historical foundational basis of the author serving as a nonautonomous subject. There are three underlying foundations to their methodology. The first is to approach a literary work as a discourse consisting of "ideological products." These ideological 
products are cultural constructs from the author's historical period and were employed by the ruling class to reinforce ideology and power structures (Abrams, 219). The precursor of this New Historicist approach derives from the Bakhtinian postulation of ideological constructs within the novel. In Discourse in the Novel, Bakhtin explains how the novel is riddled with heteroglossia, that is, an array of dialogic voices indicative of the numerous class structures in a society. Dialogic voices have been historically suppressed by the monologic language of the upper classes, which is non-evolving. Thus, it is intuited that through the study of these dialogic voices we can pinpoint specific elements of class struggles and dominant-class ideological imposition. Bakhtinian ideas of language usages in the novel were referenced to establish the existence of the cultural, economic and political linguistic signifiers, or "ideological products" within a given text. The question arises of where the author's individual voice fits into a text that is theoretically reflective of these ideological products.

The second point Bakhtin emphasizes is the non-static nature of the author's relationship with language, giving way to a new form of stylization that is parodic (302). The novel allows for the parodic stylization of "generic” and "professional” languages. Bakhtin supports his concept of language signifiers by referencing the language diversity within Charles Dickens's Little Dorrit. In his treatment of the Dickens novel, Bakhtin explains how Dickens frequently parodies a language style of the bourgeoisie utilized at formal ceremonies. This replication of formal voices, found so ubiquitously in the nineteenth century novel, is not an overt relaying of a mode of language in society. To do so would not achieve the prose of the novel, but rhetoric parody. Instead, because the parody of the novel is a stylization, Bakhtin expresses that what we find in the novel is a recreation of the monologic language in harmony with the corresponding 
dialogic languages throughout the work (heteroglossia). This in turn allows for the parodic to come off as authentic and, therefore, capable of "revealing its own world" (364).

Bakhtin also mentions the amalgamation of genres in the novel. Bakhtin expresses that this is one of the most fundamental methods of incorporating heteroglossia into the text. Multiple types of genres can be assimilated into the novel which permits a diversity of stylistic language idiosyncrasies. As "well- worked- out forms" consisting of their own languages, literary genres such as the personal letter, diary passage, and biography are ubiquitously in the novel, contributing to its unique whole. The novel, through the incorporation of genres, produces an effect on the reader of grounding the literary events in reality (realism) and relaying the events through a given character's voice (321). According to Bakhtin, the merging of genres plays an enormous role in how the belief system of the author is manifested in the text. The authorial voice and belief system can remain present through impersonation of a character's first person belief system, as demonstrated in that character's own written text, such as a letter or dairy entry. The inclusion of these genres, therefore, allows the author to become omnipresent at all times throughout the novel. Through the utilization of a character's first-person account, such as a journal entry or letter to another character, the author is able to mask their "voice" while enforcing their belief system within the novel.

These three Bakhtinian examples within Discourse in the Novel underscore Bakhtin's belief that the novel, with its basis in realism, is a revolutionary and highly influential medium which allows an authorial belief system to be creatively manifested through various styles. New Historicism upholds the belief that the humanism in a literary text, as shared by the author and characters, is an "ideological illusion," and that an author is a non-autonomous individual generating a creative work (Abrams, 221). New Historicists incorporated Bakhtin’s analysis of 
dialogic principles to establish the existence of hidden, oppressed voices within literary texts but did not address Bakhtin's belief that fiction could serve as a reactionary statement against those oppressive powers.

For Bakhtin, heteroglossia in a novel does not mean the author's belief system is nonexistent, but that the author's intentions can be found in the many languages he or she employs in the work (314). In this regard, the author is omnipresent and his or her ideology is masked in the discourse between two or more "voices." Bakhtin does not view this as a stifling of the author, or an entrapment, or loss of the authorial belief system in a text. Instead, Bakhtin views this "refraction" as empowering, referring to it as a "freedom" (314). The author’s freedom to transfer one's own intentions from one language to another, from narrator to character for instance, allows the author to never need to fully define himself in language. In this case, although the author does address the ideological products of his or her society, he remains an all-empowering agent actively aware of their ability to hide his own belief system within his text. In this light, Bakhtin’s empowered author is far different from the "unfree” author Greenblatt referenced.

Bakhtin's work, taken away from its context of Soviet materialism in the 1930's, was reappropriated by American scholars in the 1980's in light of Post-Structuralist criticism. American critics utilized Bakhtin's analysis to establish ideological formations in the language of literature, but little focus was given to his ideas of the empowerment of the "free" author.

We have established the origins of New Historical appropriation of Bakhtin's analysis of oppressed lower-class voices, resulting in its methodological search for "ideological products." Let us turn to the second foundation that contributed to New Historicist methodology, the school's belief that literature is one of many representative texts of an era. Literature is not 
recognized as unique from any other texts of the studied time period, including religious and scientific works (Abrams 220). The author cannot be considered autonomous since the literary text itself is not autonomous, literature being just one of many socially constructed representations from a period in history. For New Historicists, it is pointless to consider a literary text as a cohesive set of fixed meanings ultimately formulating a unified whole. The text ceases to be autonomous when viewed through the lens of social construction. Whereas postWorld War II New Criticism interpreted texts as artistically formulated sets of meanings, New Historicists rejected this belief and instead perceive authors as never able to fully resolve the social conflicts presented in their work, precisely because social conflicts are never fully resolved in a given historical period.

As a reference point to this Post-Structuralist concept, let us now turn to Foucault's analysis of the author in What is an Author? (1969). Foucault first addresses the need to define what constitutes a literary work. He bases this on the overall theoretical idea that "authorship" has grown to mean something entirely different in Western Culture. A major problem rests in the inability to empirically define what the term "work" of an author means. To counter this problem, Foucault comes up with the definition of the "author function," which is primarily that the author is a construct of social institutions that determine discourse. As a circulator of discourse, the author is a result of the burgeoning capitalist market of the modern state, before which, author anonymity was common in the publication of texts. The title of "author" is a functional device of classification used to differentiate texts from one another (123). Furthermore, we "project" the aspects of an author as a way to better define and coordinate texts, in order to formulate continuities or to define traits we deem most important within the work, and these projections can vary from culture to culture and in different time periods (127). Since 
the author is a term designated for a form of discourse, Foucault ends his essay by stressing that it is someday conceivable to circulate discourse without any need of an author (138).

Foucault’s essay was momentously influential on American New Historicism, first by suggesting that the designating of an author to a text is a social construction resulting from various socio-historical factors and, secondly, by emphasizing a capitalistic motivator in the need for an author. But there is grave fallacy in Foucault's essay, and subsequently, New Historicism: the intuition that historical fact stands as an entity separate and unchanging from our more “open” interpretation of literature, and that all literature should be utilized to reflect history, which is determinable and universally agreed upon. Rather, the collective concept of history is constantly evolving and dynamic, and the critic's approach to literature should not be perceived as “open” for reinterpretation but instead as grounded in empirical observations of a given historical period that all critics agree upon. That being said, a literary text can help us better understand history because a single, verifiable author represented it, not because it evidences a broad spectrum of historical reality that any "subject" could have constructed. Only by doing this can we begin to establish which literary works were most influential to its readers, thus serving both purposes of evidencing a historical period and alluding to that period's oncoming political, cultural, and ideological shifts.

In his introduction to The Western Canon (1994), Harold Bloom writes a controversial polemic against New Historicists. His work attempts to map the influence of writers belonging to the Western “canon,” showing that every great writer has been influenced by a writer preceding him or her. The "canon” is in jeopardy according to Bloom, and he writes that he finds it "absurd and regrettable” that an author like Shakespeare is critiqued through a New Historical lens, reducing him to the “'social energies’ of the English Renaissance” (3). Bloom perceives this 
reduction with disdain because Shakespeare, arguably the most influential writer in the English language, has been aesthetically lumped into comparability with less significant writers. One of the reasons, according to Bloom, is due to a trend in schools to discard aesthetics. In trying to "expand the canon” by including all forms of literature previously neglected in history, scholars have instead destroyed the canon (7).

Bloom's call for the return to detecting the aesthetic value and originality in texts demonstrates that a trend pervades literary criticism to discount author originality. Bloom mentions how critics and readers alike forget that the Western worship of God is in fact the worship of literary characters. The figures, images, social-structures, and morality in the Bible, Koran, and other texts of worship were originally imaginative representations written by individuals. Even though they have been re-imagined and restructured over the centuries, this does not diminish the fact that an autonomous artist first created them. Religious texts have governed cultures, and it should be assumed that imaginative representation from an author can produce the same effect on readers at any given historical period. This counters the New Historicist view that literature should be lumped together with all texts of a given era. The imaginative text is most capable of being carried over from generation to generation and having a greater effect on history and culture. By studying author intentions we can pinpoint why certain works of literature were more influential than others and perhaps determine which contemporary texts carry the potential to shape and manipulate our own ideological structures currently at play. 


\section{$\underline{\text { Works Cited }}$}

Abrams, M. H. A Glossary of Literary Terms. Ninth Ed. Boston: Wadsworth Cenage, 2009.

Bakhtin, Mikhail M. "Discourse in the Novel.” The Dialogic Imagination. Ed. Michael Holquist. Austin: University of Texas Press, 1981. 259-422.

Bloom, Harold. “The Western Canon. New York: Harcourt Brace and Company, 1994. 1-12.

Foucault, Michel. "What is an Author.” Language, Counter-Memory, Practice: Selected essays and Interviews. Ithaca: Cornell University Press, 1977.

Greenblatt, Stephen. The Power of Forms in the English Renaissance. Norman, Oklahoma: Pilgrim Books, 1982. 1-6.

Greenblatt, Stephen. Renaissance Self-Fashioning. Chicago: University of Chicago Press, 1980. $1-10,255-257$. 